\title{
DAX1 Deficiency
}

National Cancer Institute

\section{Source}

National Cancer Institute. DAX1 Deficiency. NCI Thesaurus. Code C120374.

Decreased activity of the nuclear receptor protein DAX1, caused by mutation(s) in the NROB1 gene (on the X chromosome), resulting in adrenal hypoplasia congenita that may be associated with hypogonadotropic hypogonadism. 